\section{Developing Protocols for Fall Sweet Corn Production in the South-central United States}

\author{
Brian A. Kahn ${ }^{1,2}$ and Lynn P. Brandenberger ${ }^{1}$
}

AdDitional Index words. Zea mays, autumn, farm-to-school, Lepidoptera, local foods, pesticides, transgenic cultivars

SUMMARY. Field studies were conducted in Oklahoma from 2010 to 2012 to develop protocols for fall sweet corn (Zea mays) production. Variables examined included a transgenic cultivar that expresses the CryIA(b) toxin from the bacterium Bacillus thuringiensis $(\mathrm{Bt})$ and its nontransgenic near-isoline, seeding rates and planting dates, and various insecticide regimens. We found that, in eastern Oklahoma, a suitable planting window would correspond roughly to the last 2 weeks in July. Within this favorable period and given timely irrigation, it was possible to sow corn to an acceptable stand. A seeding rate $\approx 1^{1 / 2}$ times the desired final stand of one plant/ft appeared to be satisfactory. Use of a cultivar (GSS-0966) with genetic resistance to lepidopteran pests was a critical factor for successful production of fall sweet corn. Efforts to produce a crop with a nontransgenic cultivar using insecticides with relatively low mammalian toxicity were unsuccessful. Our experiments support previous recommendations for applying supplemental insecticides to transgenic Bt sweet corn to potentially increase production of "premium" ears by reducing the percentage of ears with severe insect damage (damage $>1 \frac{1 / 2}{2}$ inches from the cob tip). We demonstrated that a spray schedule that rotated two insecticides with intermediate mammalian toxicity (carbaryl and permethrin) was as effective in reducing severe insect damage to ears of 'GSS-0966' as a similar schedule that rotated two highly toxic insecticides (esfenvalerate and methomyl).

S easonality may be the single greatest constraint to the expansion of local vegetable production (Offner, 2011). The impact is especially critical for certain vegetables that might contribute to farmto-school marketing programs. Such programs connect schools with local farms to improve the nutrition of school meals, increase agricultural literacy, and support local producers (Kish, 2008). For example, seasonal availability was the main perceived obstacle to increasing local food

Department of Horticulture and Landscape Architecture, 358 Agricultural Hall, Oklahoma State University, Stillwater, OK 74078-6027

Approved for publication by the Director, Oklahoma Agricultural Experiment Station.

This material is based on work that was supported in part by the National Institute of Food and Agriculture, U.S. Department of Agriculture, under project H-2026. Support also was provided by Specialty Crop Block Grant 12-25-B-0944, administered through the Oklahoma Department of Agriculture, Food, and Forestry.

We gratefully acknowledge the technical assistance of Lynda Carrier and Dan Swart.

The information given in this publication is for educational purposes only. Mention of a trademark, proprietary product, or vendor does not constitute a guarantee or warranty of the product, nor does it imply approval or disapproval to the exclusion of other products or vendors that may also be suitable.

${ }^{1}$ Professor

${ }^{2}$ Corresponding author. E-mail: brian.kahn@okstate. edu. usage in a survey of Maryland schools (Dimitri et al., 2012).

Oklahoma is representative of the south-central United States, where fresh sweet corn primarily is a summer crop. Historically, production of a fall sweet corn crop in this region (that would be available during the typical September to December fall semester of a school year) has been constrained by insect pressure. The primary pests are Lepidoptera larvae, chiefly fall armyworm (Spodoptera frugiperda) and corn earworm (Helicoverpa zea) (Brandenberger et al., 2014). Transgenic sweet corn cultivars that express the $\operatorname{CryIA(b)}$ toxin from the bacterium Bt have been available since about 1998 (Lynch et al., 1999a). These Bt sweet corn cultivars have provided excellent control of Lepidoptera larvae (Burkness et al., 2002; Lynch et al., 1999b; Musser and Shelton, 2003), thereby increasing the chances of a successful fall crop. While larval densities typically are reduced on transgenic sweet corn compared with non-Bt corn, damage is not completely eliminated (Burkness et al., 2002; Farrar et al., 2009). Therefore, programs that combine transgenic cultivars and chemical insecticides have been tested to further reduce insect damage (Farrar et al., 2009; Lynch et al., 1999b; Musser and Shelton, 2003; Speese et al., 2005). However, these tests have not occurred under the combination of hot weather and high pest densities typical of the fall production season for sweet corn in the southcentral United States. Further, investigators have focused on insect damage and have not considered other marketability factors, particularly cob fill and the degree of kernel development, which may be adversely affected by high temperatures.

A transgenic yellow sweet corn cultivar, GSS-0966, that expresses the CryIA(b) toxin (Nuessly et al., 2007) has been shown to be well adapted to Oklahoma conditions during the traditional (April to July) growing season. More information is needed on stand establishment and crop development of this cultivar during the hot summer months. Some potential customers for fall sweet corn may be concerned about the use of a genetically engineered cultivar. Therefore, we included 'Garrison', a nontransgenic near-isoline of 'GSS-0966', in one of our experiments. Customers, particularly schools, also may desire corn grown using insecticides with relatively low mammalian toxicity, or those listed by the Organic Materials Review Institute (OMRI). OMRIlisted insecticides include botanicals, microbials, insecticidal soaps, and

\begin{tabular}{llll}
\hline $\begin{array}{l}\text { Units } \\
\begin{array}{l}\text { To convert U.S. to SI, } \\
\text { multiply by }\end{array}\end{array}$ & U.S. unit & SI unit & $\begin{array}{l}\text { To convert SI to U.S., } \\
\text { multiply by }\end{array}$ \\
\hline 73.0778 & $\mathrm{fl} \mathrm{oz} / \mathrm{acre}$ & $\mathrm{mL} \cdot \mathrm{ha}^{-1}$ & 0.0137 \\
0.3048 & $\mathrm{ft}$ & $\mathrm{m}$ & 3.2808 \\
2.54 & inch $(\mathrm{es})$ & $\mathrm{cm}$ & 0.3937 \\
0.4536 & $\mathrm{lb}$ & $\mathrm{kg}$ & 2.2046 \\
1.1209 & $\mathrm{lb} / \mathrm{acre}$ & $\mathrm{kg} \cdot \mathrm{ha}^{-1}$ & 0.8922 \\
28.3495 & $\mathrm{oz}$ & $\mathrm{g}$ & 0.0353 \\
70.0532 & $\mathrm{oz} / \mathrm{acre}$ & $\mathrm{g} \cdot \mathrm{ha}^{-1}$ & 0.0143 \\
2.2417 & ton $(\mathrm{s}) / \mathrm{acre}$ & $\mathrm{Mg} \cdot \mathrm{ha}^{-1}$ & 0.4461 \\
$\left({ }^{\circ} \mathrm{F}-32\right) \div 1.8$ & ${ }^{\circ} \mathrm{F}$ & ${ }^{\circ} \mathrm{C}$ & $\left({ }^{\circ} \mathrm{C} \times 1.8\right)+32$
\end{tabular}


semiochemicals (Balusu and Fadamiro, 2012). Therefore, we included some less toxic insecticides in two of our experiments. Insecticides and fungicides used across the 3-year study are given in Table 1 .

The overall objectives of this study were to 1) manipulate seeding rates and planting dates so as to achieve successful stand establishment of sweet corn in the summer and an extended harvest period during the fall, and 2) study the use of a transgenic cultivar and various insecticides with the goal of producing fall sweet corn ears that will meet fresh market standards.

\section{Materials and methods}

2010. This study was conducted at the Oklahoma Vegetable Research Station, Bixby, on a Severn very fine sandy loam [coarse-silty, mixed (calcareous), thermic Typic Udifluvent]. The objective was to compare two seeding treatments on each of five planting dates for production of fall sweet corn. Dates for key cultural practices and details of pesticide applications are given in Table 2 . The design was a randomized complete block with four replications and a split-plot arrangement of treatments. Planting dates were assigned to main plots consisting of eight 20 -ft-long rows spaced $3 \mathrm{ft}$ apart. Each main plot was bordered on all sides by a 12 -ft-wide tilled alley. The two seeding treatments each were assigned to four-row subplots, consisting of the eastern or western four rows of a main plot. The center two rows of each subplot were used for data collection. The cultivar was GSS-0966.

Following final tillage, a tractordrawn, cone-type plot seeder (Hege Equipment, Colwich, KS) was used to sow plots on each planting date. One cone supplied two rows per pass in each main plot. Packets of 60 seeds per pass were used for the "sown to stand" treatment, for a rate of about 30 seeds $/ 20 \mathrm{ft}$ of row. Packets of 100 seeds per pass were used for the "thinned to stand" treatment, for a rate of about 50 seeds $/ 20 \mathrm{ft}$ of row. A herbicide was applied after seeding for weed control (Table 2 ). Stand counts were made about 2 weeks after planting, at which time the "thinned to stand" subplots were hand thinned to 20 plants $/ 20 \mathrm{ft}$ of row to provide a uniform, idealized comparison for the "sown to stand" plots for each planting date. Each main plot received a total of $150 \mathrm{lb} /$ acre of nitrogen $(\mathrm{N})$, applied as three topdressings of $50 \mathrm{lb} /$ acre of $\mathrm{N}$ each using urea (Table 2). Sprinkler irrigation was used to supplement natural rainfall.

This study focused on effects related to stand establishment. Care was taken to balance cultural practices across the five planting dates as much as possible. The number of postsilking pesticide applications (those directly affecting ear quality) per planting date was either two (the two latest plantings, 2 and 12 Aug.) or three (the three earlier plantings) (Table 2).

Plots from each planting date were harvested once by hand when it appeared that most primary ears had reached marketable maturity. All ears that were large enough to snap were harvested, including secondary ears. Once out of the field, all ears were stripped to expose most of the kernels without detaching the shucks; this made grading more precise. Ears were sorted into four categories: marketable, cull primarily due to irregular or inadequate cob fill, cull primarily due to insect (Lepidoptera larvae, mostly corn earworm) damage or disease (mostly smut, incited by Ustilago maydis) that would exceed U.S. No. 1 grade standards, and cull due to underdevelopment of kernels on the ear. Ears in each category were counted and weighed. Five marketable ears per subplot were sampled for diameter and length and rated for insect damage. Insect damage ratings were made using a scale of $1=$ no damage to $5=$ damage $>1 \frac{1}{2}$ inches from the tip of the cob. Finally, height from the soil to the point of primary ear attachment was measured on six plants per subplot. These plants were cut at their bases and dried for $7 \mathrm{~d}$ at $135{ }^{\circ} \mathrm{F}$, after which weights were recorded.

Table 1. Insecticides and fungicides used in research on fall sweet corn from 2010 to 2012 at Bixby and Stillwater, OK.

\begin{tabular}{|c|c|c|c|c|c|}
\hline Common name & Trade name & Manufacturer & Category & $\begin{array}{c}\text { Acute oral } \\
\mathrm{LD}_{50}\left(\mathrm{mg} \cdot \mathrm{kg}^{-1}\right)^{\mathrm{z}} \\
\end{array}$ & $\begin{array}{c}\text { Signal } \\
\text { word }\end{array}$ \\
\hline Esfenvalerate & Asana & DuPont, Wilmington, DE & Insecticide & 458 & Warning \\
\hline $\mathrm{Bt}^{\mathrm{y}}$ (Strain ABTS) & Dipel & Valent, Libertyville, IL & Insecticide & $>5,050$ & Caution \\
\hline N.p.virus ${ }^{\mathrm{x}}$ & Gemstar & Certis USA, Columbia, MD & Insecticide & $>5,000$ & Caution \\
\hline $\mathrm{Bt}^{\mathrm{y}}($ Strain $\mathrm{SA})$ & Javelin & Certis USA & Insecticide & $>5,000$ & Caution \\
\hline Zeta-cypermethrin & Mustang Maxx & FMC Corp., Philadelphia, PA & Insecticide & 310 & Warning \\
\hline Permethrin & PermaStarw & LG Intl., Englewood Cliffs, NJ & Insecticide & 998 & Caution \\
\hline Permethrin & Pounce $^{w}$ & FMC Corp. & Insecticide & $>2,000$ & Caution \\
\hline Pyrethrins & PyGanic & MGK, Minneapolis, MN & Insecticide & $>2,000$ & Caution \\
\hline Azoxystrobin & Quadris & Syngenta & Fungicide & $>5,000$ & Caution \\
\hline
\end{tabular}

${ }^{z} \mathrm{LD}_{50}=$ dosage required to kill $50 \%$ of a test population. Details are available on the material safety data sheet for each pesticide. $1 \mathrm{mg} \cdot \mathrm{kg}{ }^{-1}$ of body weight $=1.6 \times 10^{-5} \mathrm{oz} / \mathrm{lb}$ of body weight.

${ }^{\mathrm{y}} \mathrm{Bt}=$ Bacillus thuringiensis $\mathrm{ssp}$. kurstaki.

${ }^{\mathrm{x}} \mathrm{N} . \mathrm{p}$. virus = polyhedral occlusion bodies of the nuclear polyhedrosis virus of Helicoverpa zea.

wTo different permethrin products were used. Pounce was used in 2010 while PermaStar was used in 2011 and 2012. 
Table 2. Dates for key cultural practices used in the 2010 fall sweet corn study at Bixby, OK. The nitrogen (N) fertilizer used was urea. Bold text indicates postsilking pesticide applications. ${ }^{\mathrm{z}}$

\begin{tabular}{|c|c|c|c|c|c|}
\hline Planting & 1 July & 15 July & 23 July & 2 Aug. & 12 Aug. \\
\hline Herbicide & $\begin{array}{l}\text { 1 July: } \\
\text { S-metolachlor } \\
\text { (11.4 oz/acre })\end{array}$ & $\begin{array}{l}16 \text { July: } \\
\text { S-metolachlor } \\
\text { (11.4 oz/acre })\end{array}$ & $\begin{array}{l}23 \text { July: } \\
\text { S-metolachlor } \\
\text { (11.4 oz/acre })\end{array}$ & $\begin{array}{l}2 \text { Aug.: } \\
\text { S-metolachlor } \\
\text { (11.4 oz/acre })\end{array}$ & $\begin{array}{l}12 \text { Aug.: } \\
S \text {-metolachlor } \\
(11.4 \mathrm{oz} / \text { acre })\end{array}$ \\
\hline $\begin{array}{l}\text { Stand counts } \\
\text { and } \\
\text { thinning }\end{array}$ & 15 July & 27 July & 5 Aug. & 16 Aug. & 26 Aug. \\
\hline Fertilizer & $\begin{array}{l}27 \text { July: N } \\
(50 \mathrm{lb} / \mathrm{acre})\end{array}$ & $\begin{array}{l}5 \text { Aug.: N } \\
(50 \mathrm{lb} / \text { acre })\end{array}$ & $\begin{array}{l}16 \text { Aug.: N } \\
(50 \mathrm{lb} / \text { acre })\end{array}$ & $\begin{array}{l}26 \text { Aug.: N } \\
(50 \mathrm{lb} / \text { acre })\end{array}$ & $\begin{array}{l}7 \text { Sept.: N } \\
\quad(50 \mathrm{lb} / \text { acre })\end{array}$ \\
\hline Fertilizer & $\begin{array}{l}16 \text { Aug.: N } \\
\quad(50 \mathrm{lb} / \text { acre })\end{array}$ & $\begin{array}{l}30 \text { Aug.: N } \\
\quad(50 \mathrm{lb} / \mathrm{acre})\end{array}$ & $\begin{array}{l}7 \text { Sept.: N } \\
\quad(50 \mathrm{lb} / \text { acre })\end{array}$ & $\begin{array}{l}21 \text { Sept.: N } \\
\quad(50 \mathrm{lb} / \text { acre })\end{array}$ & $\begin{array}{l}30 \text { Sept.: N } \\
\quad(50 \mathrm{lb} / \text { acre })\end{array}$ \\
\hline Insecticide & $\begin{array}{l}19 \text { Aug.: } \\
\text { esfenvalerate } \\
(0.66 \mathrm{oz} / \text { acre })\end{array}$ & & & & \\
\hline Insecticide & $\begin{array}{l}30 \text { Aug.: } \\
\text { esfenvalerate } \\
(0.66 \mathrm{oz} / \text { acre })\end{array}$ & $\begin{array}{l}30 \text { Aug.: } \\
\text { esfenvalerate } \\
(0.66 \mathrm{oz} / \text { acre })\end{array}$ & & & \\
\hline $\begin{array}{l}\text { Insecticide } \\
\text { and } \\
\text { fungicide }\end{array}$ & & $\begin{array}{l}7 \text { Sept.: permethrin } \\
\text { (3.2 oz/acre) }+ \\
\text { azoxystrobin } \\
(2.86 \mathrm{oz} / \text { acre })\end{array}$ & & & \\
\hline $\begin{array}{l}\text { Insecticide } \\
\text { and } \\
\text { fungicide }\end{array}$ & & $\begin{array}{l}16 \text { Sept.: malathion } \\
\text { (20 oz/acre })+ \\
\text { chlorothalonil } \\
(24 \mathrm{oz} / \text { acre })\end{array}$ & $\begin{array}{l}\text { 16 Sept.: malathion } \\
\text { (20 oz/acre) } \\
+ \text { chlorothalonil } \\
(24 \mathrm{oz} / \text { acre })\end{array}$ & & \\
\hline Insecticide & & & & $\begin{array}{l}12 \text { Oct.: } \\
\text { esfenvalerate } \\
(0.66 \mathrm{oz} / \text { acre })\end{array}$ & $\begin{array}{l}12 \text { Oct.: } \\
\text { esfenvalerate } \\
(0.66 \mathrm{oz} / \text { acre })\end{array}$ \\
\hline Insecticide & & & & & $\begin{array}{l}27 \text { Oct.: } \\
\text { zeta-cypermethrin } \\
(0.4 \mathrm{oz} / \text { acre })\end{array}$ \\
\hline Harvest & 7 Sept. & 21 Sept. & 30 Sept. & 20 Oct. & 4 Nov. \\
\hline
\end{tabular}

${ }^{\mathrm{z}}$ Pesticide rates are in ounces of active ingredient per acre; $\mathrm{l} \mathrm{oz} / \mathrm{acre}=70.0532 \mathrm{~g} \cdot \mathrm{ha}^{-1}, \mathrm{l} \mathrm{lb} / \mathrm{acre}=1.1209 \mathrm{~kg} \cdot \mathrm{ha}^{-1}$.

2011. This study was conducted at the Oklahoma Entomology and Plant Pathology Research Farm, Stillwater on a Norge loam (fine-silty, mixed, active, thermic Udic Paleustoll). The objective was to evaluate four insecticide regimens (plus a nontreated control that could be considered Regimen 1) on the sweet corn cultivars GSS-0966 and Garrison. A presilking insecticide application was made to all plots except the controls on 25 Aug. due to some foliar damage. Postsilking insecticide applications were made twice a week beginning on 13 Sept. and continuing through 6 Oct. (details follow). Regimen 2 was a foliar spray of $B$. thuringiensis ssp. kurstaki Strain ABTS (8.6 oz/acre) on 25 Aug. followed by foliar sprays of $B$. thuringiensis ssp. kurstaki Strain SA (10.2 $\mathrm{oz} /$ acre) on 13, 23, and 30 Sept. and 6 Oct. alternated with nuclear polyhedrosis virus $[7 \mathrm{fl} \mathrm{oz} /$ acre of product that was $0.64 \%$ a.i. (weight of active ingredient per unit of product not provided on label)] on 19 and 27 Sept. and 3 Oct. Regimen 3 was similar to Regimen 2, but foliar sprays of pyrethrins [ $12 \mathrm{fl} \mathrm{oz} /$ acre of product that was $5 \%$ a.i. (weight of active ingredient per unit of product not provided on label)] were used instead of nuclear polyhedrosis virus. Regimen 4 was similar to Regimen 2, but foliar sprays of spinosad (1.1 oz/acre) were used instead of nuclear polyhedrosis virus. Regimen 5 was foliar 
sprays of carbaryl (24 oz/acre) on 25 Aug. and 13, 23, and 30 Sept. and 6 Oct. alternated with foliar sprays of permethrin $(2.4 \mathrm{oz} /$ acre $)$ on 19 and 27 Sept. and 3 Oct.

The design was a split-block with four replications. The two cultivars were planted in three-row strips across an entire block of pesticide treatment plots. Each pesticide treatment plot consisted of six 20-ft-long rows spaced $3 \mathrm{ft}$ apart. The four center rows (two per cultivar) were used for data collection. Each pesticide treatment plot was bordered on all sides by a 12 -ft-wide tilled alley.

A preplant-incorporated application of urea to supply $50 \mathrm{lb} /$ acre of $\mathrm{N}$ was made on 27 July, after which the same plot seeder that had been used in 2010 was used to sow plots. The seeding rate was about 30 seeds $/ 20 \mathrm{ft}$ of row, similar to the "sown to stand" rate used in 2010. The herbicide $S$-metolachlor was applied after seeding at $11.4 \mathrm{oz} /$ acre for weed control. Sprinkler irrigation was used to supplement natural rainfall.

A count on 14 Aug. showed that rows averaged 27 seedlings $/ 20 \mathrm{ft}$ of row, but we did not want stand variation to potentially affect experimental results. Therefore, on 16 Aug., rows were thinned so that control and insecticide regimen plots all averaged 21 plants $/ 20 \mathrm{ft}$ of row. All plots were top-dressed with urea to supply $50 \mathrm{lb} /$ acre of $\mathrm{N}$ on $18 \mathrm{Aug}$. and to supply $75 \mathrm{lb} /$ acre of $\mathrm{N}$ on 11 Sept.

Plots were harvested once by hand on 10 Oct. Only full-size ears were harvested. Ears were husked and divided into containers based on

Table 3. Effects of planting date and seeding rate on stand establishment, height to primary ear, and stalk dry weight after harvest of 'GSS-0966' fall sweet corn at Bixby, OK, in 2010.

\begin{tabular}{|c|c|c|c|}
\hline Variable & $\begin{array}{c}\text { Stand } \\
(\text { plants } / 20 \mathrm{ft})^{\mathrm{z}}\end{array}$ & $\begin{array}{l}\text { Ht to primary } \\
\text { ear (inches) }\end{array}$ & $\begin{array}{c}\text { Stalk dry } \\
\text { wt }(\mathrm{oz} / \text { plant })^{\mathrm{z}}\end{array}$ \\
\hline \multicolumn{4}{|l|}{ Planting date } \\
\hline I July & $24 \mathrm{a}^{\mathrm{y}}$ & $14 \mathrm{~b}$ & $2.4 \mathrm{c}$ \\
\hline 15 July & $20 \mathrm{~b}$ & $15 \mathrm{~b}$ & $5.1 \mathrm{a}$ \\
\hline 23 July & $20 \mathrm{~b}$ & $14 \mathrm{~b}$ & $3.5 \mathrm{~b}$ \\
\hline 2 Aug. & $21 \mathrm{~b}$ & $17 \mathrm{a}$ & $2.6 \mathrm{c}$ \\
\hline 12 Aug. & $21 \mathrm{~b}$ & $14 \mathrm{~b}$ & $2.7 \mathrm{c}$ \\
\hline Main effect & * & * & $* *$ \\
\hline \multicolumn{4}{|c|}{ Seeding rate $(\text { seeds } / 20 \mathrm{ft})^{\mathrm{z}}$} \\
\hline 30 & 22 & 37 & 3.3 \\
\hline 50 & 20 & 38 & 3.3 \\
\hline Main effect & ** & NS & NS \\
\hline Date $\times$ seeding rate & * & NS & NS \\
\hline
\end{tabular}

whether they were filled, partially filled but still marketable, or so poorly filled as to be culls regardless of insect damage. Ears in each category then were counted and stored at $40{ }^{\circ} \mathrm{F}$ for insect damage grading, which took place by replication from 12 to 14 Oct. Within each of the three fill categories, ears were sorted into insect damage categories of no damage, damage $\leq 1$ inch from ear tip, damage $\leq 1 \frac{1}{2}$ inches from ear tip, and damage $>1 \frac{1}{2}$ inches from ear tip and/or any damage low on the cob regardless of tip damage. Ears then were counted, creating an ear quality matrix based on 12 possible combinations of cob fill and insect damage.

2012. This study was conducted at the Oklahoma Entomology and Plant Pathology Research Farm, Stillwater on a Norge loam. The objective was to evaluate three insecticide regimens (plus a nontreated control that could be considered Regimen 1) on the cultivar GSS0966. A presilking insecticide application was made to all plots except the controls on 23 Aug. due to some foliar damage. Postsilking insecticide applications were made twice a week beginning on 6 Sept. and continuing through 2 Oct. (details follow). Insecticide regimen numbers began with the number six to avoid confusion with the 2011 experiment. Regimen 6 was foliar sprays of nuclear polyhedrosis virus $[7 \mathrm{fl} \mathrm{oz} /$ acre of product that was $0.64 \%$ a.i. (weight of active ingredient per unit of product not provided on label)] on 23 Aug. and 6, 17, and 25 Sept. and 2 Oct. alternated with foliar sprays of spinosad (1.1 oz/acre) on 11,21, and 28 Sept. Regimen 7 was foliar sprays of carbaryl (24 oz/acre) on 23 Aug.

Table 4. Effects of summer planting dates on production of marketable 'GSS-0966' fall sweet corn ears at Bixby, OK, in 2010.

\begin{tabular}{|c|c|c|c|c|c|c|c|}
\hline \multirow[b]{2}{*}{$\begin{array}{l}\text { Planting } \\
\text { date }\end{array}$} & \multicolumn{7}{|c|}{ Marketable ears } \\
\hline & $\begin{array}{l}\text { Proportion of total } \\
\text { ears harvested }(\%)\end{array}$ & $\begin{array}{c}\text { Count } \\
(1,000 / \mathrm{ha})^{\mathrm{z}} \\
\end{array}$ & 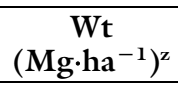 & $\begin{array}{c}\text { Avg } \\
\text { wt }(g)^{z}\end{array}$ & $\begin{array}{l}\text { Diam } \\
(\mathrm{cm})^{\mathrm{z}}\end{array}$ & $\begin{array}{l}\text { Length } \\
(\mathrm{cm})^{\mathrm{z}}\end{array}$ & $\begin{array}{c}\text { Insect damage } \\
(1-5 \text { scale })^{\mathrm{y}} \\
\end{array}$ \\
\hline 1 July & $10 \mathrm{~d}^{\mathrm{x}}$ & $3.8 \mathrm{~d}$ & $0.6 \mathrm{~d}$ & $164 \mathrm{c}$ & $3.9 \mathrm{~d}$ & $13.3 \mathrm{c}$ & $2.8 \mathrm{a}$ \\
\hline 15 July & $33 \mathrm{c}$ & $14.5 \mathrm{c}$ & $3.0 \mathrm{c}$ & $203 \mathrm{~b}$ & $4.2 \mathrm{c}$ & $16.8 \mathrm{~b}$ & $2.4 \mathrm{~b}$ \\
\hline 23 July & $72 \mathrm{~b}$ & $32.5 \mathrm{a}$ & $7.8 \mathrm{a}$ & $240 \mathrm{a}$ & $4.5 \mathrm{~b}$ & $18.0 \mathrm{a}$ & $2.1 \mathrm{c}$ \\
\hline 2 Aug. & $76 \mathrm{ab}$ & $34.1 \mathrm{a}$ & $8.2 \mathrm{a}$ & $241 \mathrm{a}$ & $4.7 \mathrm{a}$ & $17.4 \mathrm{ab}$ & $1.6 \mathrm{~d}$ \\
\hline
\end{tabular}

${ }^{2} 1,000$ ears $/ \mathrm{ha}=404.6856 \mathrm{ears} / \mathrm{acre} ; \mathrm{l} \mathrm{Mg} \cdot \mathrm{ha}^{-1}=0.4461 \mathrm{ton} / \mathrm{acre} ; \mathrm{l} \mathrm{g}=0.0353 \mathrm{oz} ; \mathrm{l} \mathrm{cm}=0.3937$ inch.

${ }^{\mathrm{y}} 1=$ no damage; $2=$ damage $\leq 1 / 2$ inch from tip; $3=$ damage $\leq 1$ inch from tip; $4=$ damage $\leq 1 \frac{1}{1} 2$ inches from tip; $5=$ damage $>1 \frac{1}{2} 2$ inches from tip; 1 inch $=2.54 \mathrm{~cm}$.

${ }^{x}$ Within columns, means followed by the same letter do not differ according to Fisher's protected least significant difference at $P \leq 0.05$.

** Significant by $\mathrm{F}$ test at $P \leq 0.01$. 
and 6, 17, and 25 Sept. and 2 Oct. alternated with foliar sprays of permethrin $(2.4 \mathrm{oz} /$ acre $)$ on 11,21 , and 28 Sept. Regimen 8 was foliar sprays of esfenvalerate $(0.66 \mathrm{oz} /$ acre $)$ on 23 Aug. and 6, 17, and 25 Sept. and 2 Oct. alternated with foliar sprays of methomyl ( $6 \mathrm{oz} /$ acre $)$ on 11,21 , and 28 Sept.

The design was a randomized complete block with four replications. Each pesticide treatment plot consisted of four $20-\mathrm{ft}$-long rows spaced $3 \mathrm{ft}$ apart. The two center rows were used for data collection. Each pesticide treatment plot was bordered on all sides by a 12 -ft-wide tilled alley.

A preplant-incorporated application of urea to supply $50 \mathrm{lb} /$ acre of $\mathrm{N}$ was made on 24 July. The next day, the same plot seeder that had been used in the previous two experiments was used to sow plots. The seeding rate was about 40 seeds $/ 20 \mathrm{ft}$ of row, as the projected percent germination was slightly lower than in 2011 . The herbicide $S$-metolachlor was applied after seeding at $11.4 \mathrm{oz} /$ acre for weed control. Sprinkler irrigation was used to supplement natural rainfall.
A count on 12 Aug. showed that most rows had 30 to 35 seedlings, so a preliminary thinning to 24 plants/ $20 \mathrm{ft}$ of row was done. A final thinning to 20 plants $/ 20 \mathrm{ft}$ of row was done on 21 Aug. All plots were topdressed with urea to supply $50 \mathrm{lb} /$ acre of $\mathrm{N}$ on 15 Aug. and to supply 75 $\mathrm{lb} /$ acre of $\mathrm{N}$ on 8 Sept.

Plots were harvested once by hand by replication from 4 to 6 Oct. Only full-size ears were harvested. Ears were husked and divided into containers based on whether they were filled, partially filled but still

Table 5. Effects of summer planting dates on production of cull 'GSS-0966' fall sweet corn ears at Bixby, OK, in 2010. Categories indicate the predominant reason why a given ear was categorized as a cull.

\begin{tabular}{|c|c|c|c|}
\hline \multirow{2}{*}{$\begin{array}{l}\text { Planting } \\
\text { date }\end{array}$} & $\begin{array}{c}\text { Full-sized ears with irregular } \\
\text { or inadequate fill }\end{array}$ & $\begin{array}{l}\text { Full-sized ears with disease } \\
\text { or excessive } \text { insect damage }^{\mathrm{z}} \text { insection }\end{array}$ & $\begin{array}{l}\text { Underdeveloped } \\
\text { ears }\end{array}$ \\
\hline & \multicolumn{3}{|c|}{$\left(\mathrm{kg} \cdot \mathrm{ha}^{-1}\right)^{\mathrm{y}}$} \\
\hline I July & $1,137 b c^{x}$ & $3,234 \mathrm{a}$ & $953 \mathrm{~d}$ \\
\hline 15 July & $2,535 \mathrm{a}$ & $2,348 \mathrm{~b}$ & $1,351 \mathrm{c}$ \\
\hline 23 July & $1,606 \mathrm{~b}$ & $1,117 \mathrm{c}$ & $1,749 \mathrm{~b}$ \\
\hline 2 Aug. & $1,434 \mathrm{~b}$ & $718 \mathrm{~cd}$ & $1,358 \mathrm{c}$ \\
\hline
\end{tabular}

${ }^{z}$ Insect damage $>1 \frac{1 / 2}{}$ inches $(3.81 \mathrm{~cm})$ from cob tip.

y $1 \mathrm{~kg} \cdot \mathrm{ha}^{-1}=0.8922 \mathrm{lb} /$ acre .

${ }^{x}$ Within columns, means followed by the same letter do not differ according to Fisher's protected least significant difference at $P \leq 0.05$.

* * Significant by $\mathrm{F}$ test at $P \leq 0.01$.

Table 6. Effects of two cultivars and five insecticide regimens on yield and quality of fall sweet corn at Stillwater, OK, in $2011 .^{\mathrm{z}}$

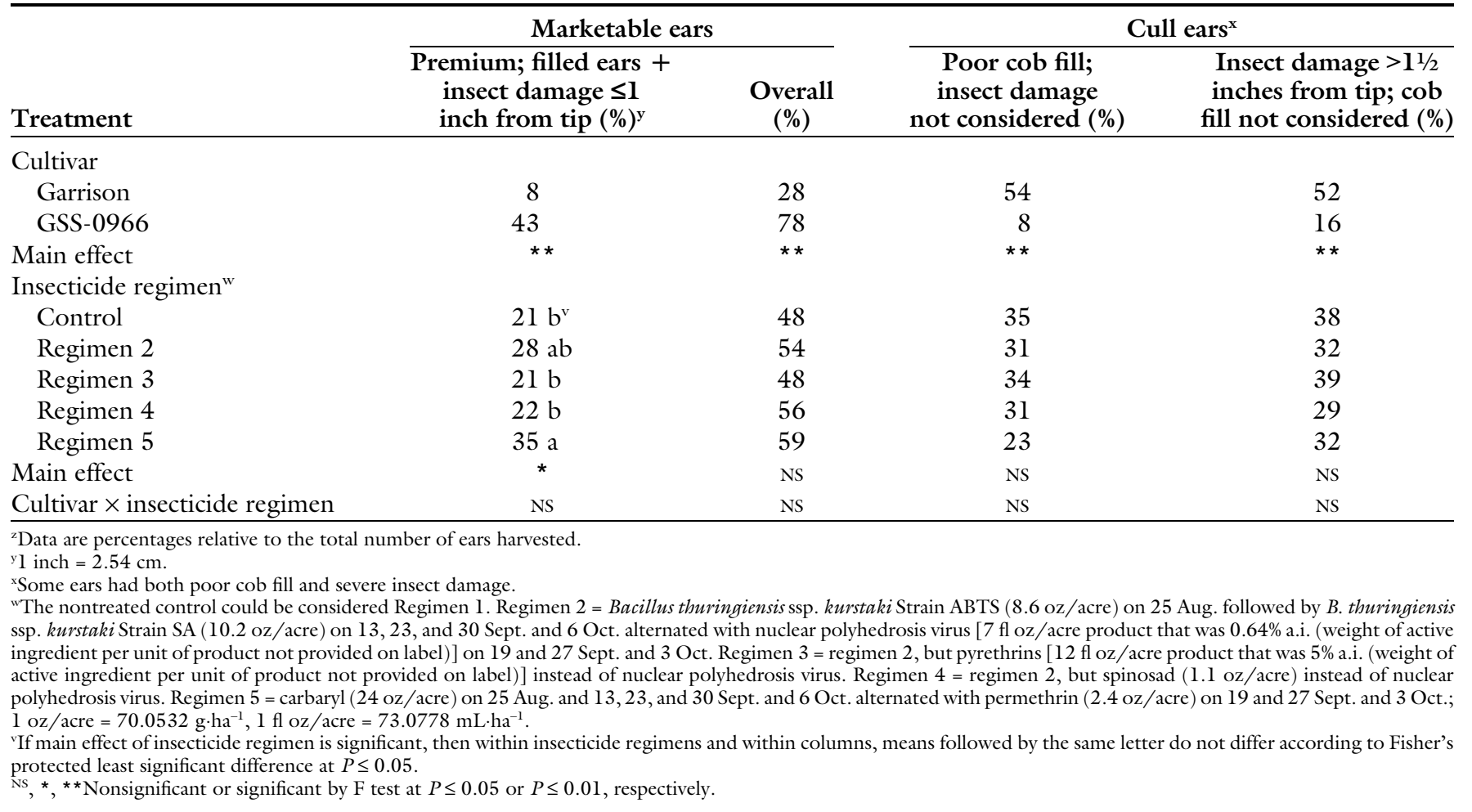


marketable, or so poorly filled as to be culls regardless of insect damage. Ears in each category then were counted, graded for insect damage using the same criteria as in 2011, and counted again to create an ear quality matrix.

Statistical ANALYSIS. Data were evaluated with analysis of variance procedures (PROC GLM) using SAS software (version 9.4; SAS Institute, Cary, NC). Main effects of planting date and seeding rate, and their interaction, were tested in the 2010 experiment. Mean separation among planting dates was by Fisher's protected least significant difference (LSD) at $P \leq 0.05$. Main effects of cultivar and insecticide regimen, and their interaction, were tested in the 2011 experiment. Main effects of insecticide regimen were tested in the 2012 experiment. Mean separation among insecticide regimens was by Fisher's protected LSD at $P \leq$ 0.05 in both the 2011 and 2012 experiments.

\section{Results and discussion}

2010. Stands before thinning averaged 22 plants $/ 20 \mathrm{ft}$ of row in the "sown to stand" treatment and 39 plants $/ 20 \mathrm{ft}$ of row in the "thinned to stand" treatment. After thinning, the only difference remaining was in plots sown on 1 July (Table 3 ). Stands averaged 28 plants $/ 20 \mathrm{ft}$ of row in the 1 July "sown to stand" plots but averaged 20 plants $/ 20 \mathrm{ft}$ of row in the 1 July "thinned to stand" plots. The interaction analysis (not presented) showed that the stand of 28 plants/ $20 \mathrm{ft}$ of row differed from all other stands after thinning, but none of the remaining post-thinning stands differed from each other. No reason was evident for the relatively high stands in the 1 July "sown to stand" plots. However, since post-thinning stands were so similar overall, neither the main effect of seeding rate nor the planting date $\times$ seeding rate interaction was significant for all but one of the measured variables associated with harvest data (Tables 3-5). The exception was insect damage rating, for which a main effect of seeding rate was evident. Ears from plants sown to stand rated 1.9 while ears from plants thinned to stand rated 2.1. The difference was small and of little practical consequence.

Height to the primary ear was affected by planting date only for

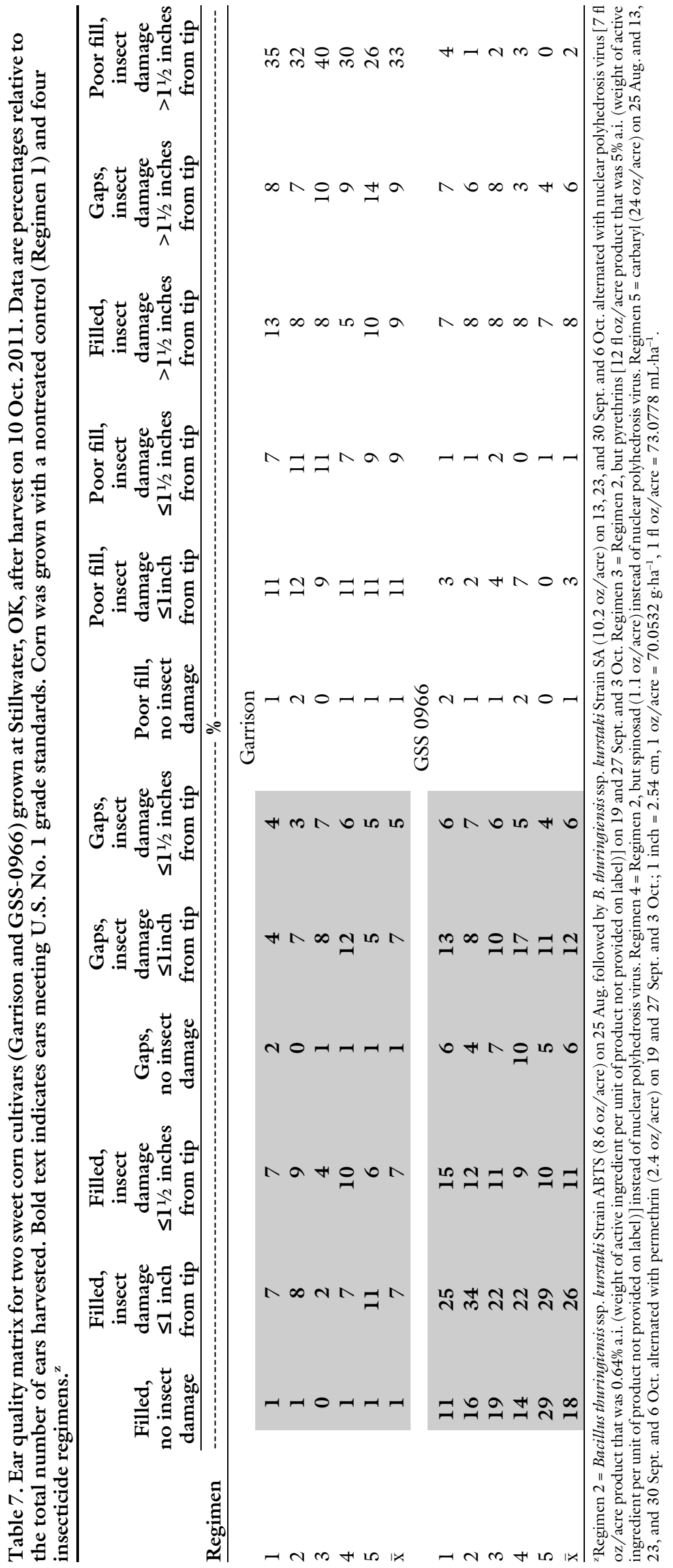

Hortlechnology $\cdot$ August 2016 26(4) 
2 Aug. (Table 3). Plants from 2 Aug. appeared relatively tall, and plants from both 2 Aug. and 12 Aug. had relatively little tillering (observations only; data were not recorded). Stalk dry weights increased from the 1 July planting to the 15 July planting and then decreased (Table 3 ). Changes in planting date modify light and temperature conditions during the growing season, and these variations ultimately impact corn crop phenology and dry matter partitioning (Brooking and McPherson, 1989; Garcia y Garcia et al., 2009; Williams, 2008).

The plants from 1 July appeared to have been under heat and moisture stress, despite supplemental irrigation. Maximum air temperatures averaged $91{ }^{\circ} \mathrm{F}$ and rainfall totaled only 6.95 inches across the $69-\mathrm{d}$ growing period. Plants from 1 July averaged $10 \%$ marketable ears, and those ears were relatively small (Table 4). Production of ears with disease or excessive insect damage was higher with the 1 July planting than with any other planting date (Table 5). Marketable ear production and average ear weight still were low with the 15 July planting (Table 4), despite relatively robust stalks (Table 3 ), and cob fill was poor (Table 5). High temperatures during silking likely interfered with seed setting (Lonnquist and Jugenheimer, 1943).

Yield and characteristics of marketable ears generally were similar with the 23 July and 2 Aug. planting dates (Tables 4 and 5). These two planting dates delineated a "window" for good production of marketable ears. Marketable ear quality remained high with the 12 Aug. planting date, but production decreased compared with the 23 July and 2 Aug. planting dates (Table 4 ). The main reason was that plants from 12 Aug. had the highest weight of underdeveloped ears in the trial (Table 5). The plants had to be harvested a few days short of prime maturity due to an impending frost $\left(30{ }^{\circ} \mathrm{F}\right)$ that occurred on the night of 5 Nov.

Insect damage to the ears decreased progressively with later planting dates (Tables 4 and 5). In terms of the total field environment, plants from the later planting dates would have benefitted from insecticides being applied to plants from the earlier planting dates. However, plants from 2 Aug. and 12 Aug. had only two postsilking pesticide applications compared with three for each of the earlier plantings (Table 2). We did not directly monitor insect populations in the field, but it appeared that insect pressure decreased as summer gave way to fall and air temperatures decreased. Malvar et al. (2002) also reported that insect damage to sweet corn was affected by the environmental conditions associated with different planting dates.

2011. Effects on quality of harvested ears were overwhelmingly due to cultivar (Table 6). Ears of 'Garrison' exhibited both poor cob fill and extensive insect damage (Tables 6 and 7). In a study without insecticide applications, Burkness et al. (2002) found that three transgenic Bt sweet corn hybrids provided $75 \%$ to $99 \%$ marketable ears for fresh market use, compared with $14 \%$ to $34 \%$ marketable ears for three non-Bt sweet corn hybrids. Musser and Shelton (2003) noted that foliar sprays of Bt have provided inconsistent control of Lepidoptera pests of sweet corn. Farrar et al. (2009) evaluated spray treatments including nuclear polyhedrosis virus, neem, and spinosad for control of Lepidoptera larvae on transgenic sweet corn, and found that only spinosad consistently reduced damage to ears. However, none of these studies reported effects of cob fill on marketability.

About $21 \%$ of the ears of 'Garrison' would have been marketable in terms of insect damage to the kernels but were culled due to poor cob fill (Table 7). This finding reinforces the need to protect the silks before kernels develop. Sweet corn silks are subject to attack by nonlepidopteran pests, such as northern corn rootworm [Diabrotica longicornis (Borror et al., 1976)]. These insects may not be controlled by Lepidopteraspecific toxins. Others (Musser and Shelton, 2003; Nuessly et al., 2007) have recommended applying supplemental insecticides to transgenic $\mathrm{Bt}$ sweet corn to reduce the potential for damage from nonlepidopteran pests. Regimen 5 (carbaryl alternated with permethrin) more than doubled the percentage of ears of 'GSS-0966' that were filled and had no insect damage compared with the control (Table 7). Thus, better protection of the silks may partially explain the increased percentage of "premium"

Table 8. Effects of four insecticide regimens on yield and quality of 'GSS-0966' fall sweet corn at Stillwater, OK, in 2012. ${ }^{2}$

\begin{tabular}{|c|c|c|c|c|}
\hline \multirow[b]{2}{*}{ Treatment } & \multicolumn{2}{|c|}{ Marketable ears } & \multicolumn{2}{|c|}{ Cull ears ${ }^{\mathrm{x}}$} \\
\hline & $\begin{array}{l}\text { Premium; filled ears }+ \\
\text { insect damage } \\
\leq 1 \text { inch from tip }(\%)^{y}\end{array}$ & $\begin{array}{c}\text { Overall } \\
(\%)\end{array}$ & $\begin{array}{l}\text { Poor cob fill; } \\
\text { insect damage not } \\
\text { considered }(\%)\end{array}$ & $\begin{array}{c}\text { Insect damage }>1 \frac{1}{1} 2 \text { inches } \\
\text { from tip; cob fill } \\
\text { not considered }(\%) \\
\end{array}$ \\
\hline \multicolumn{5}{|c|}{ Insecticide regimen $^{\mathrm{w}}$} \\
\hline Control & 43 & 77 & 4 & $21 \mathrm{a}^{\mathrm{v}}$ \\
\hline Regimen 6 & 48 & 82 & 6 & $15 \mathrm{ab}$ \\
\hline Main effect & NS & NS & NS & * \\
\hline \multicolumn{5}{|c|}{ 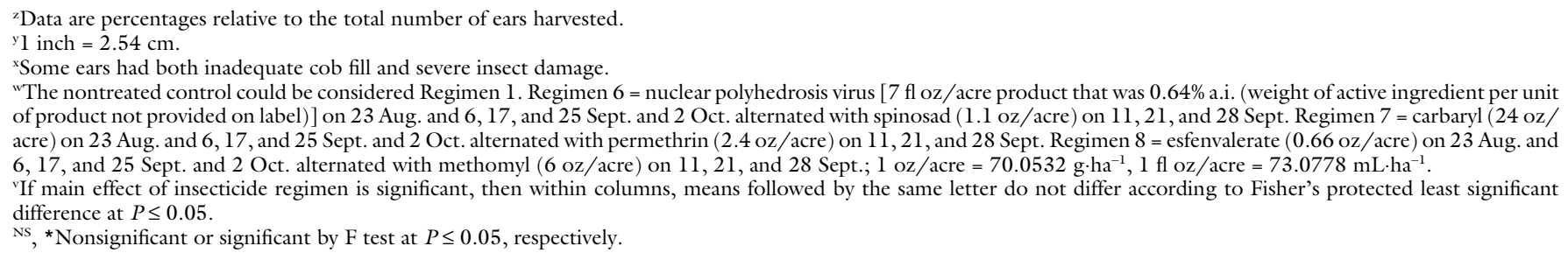 } \\
\hline
\end{tabular}


ears relative to the control resulting from Regimen 5 (Table 6). However, insecticide regimens did not affect the overall percentage of marketable ears, and no cultivar $\times$ insecticide regimen interactions were evident (Table 6).

2012. The insecticides used in 2012 were chosen to provide a range in mammalian toxicity, expressed as the dosage required to kill $50 \%$ of a test population $\left(\mathrm{LD}_{50}\right)$ (Tables 1 and 8). Materials in Regimen 6 (nuclear polyhedrosis virus alternated with spinosad) were based on OMRI-listed active ingredients. Materials in Regimen 7 (carbaryl alternated with permethrin) had $\mathrm{LD}_{50}$ values below $1000 \mathrm{mg} \cdot \mathrm{kg}^{-1}$, but still were considered "Slightly Toxic" with the signal word "Caution." Materials in Regimen 8 (esfenvalerate alternated with methomyl) had signal words "Warning" and "Danger," respectively. The results (Table 8 ) showed that, as in 2011, insecticide regimens did not affect the overall percentage of marketable ears. However, Regimens 7 and 8 did reduce the percentage of ears with severe insect damage compared with the control (Table 8). This contributed to an improvement of $15 \%$ or more in "premium" ears (Table 8). The $15 \%$ increase approached statistical significance $(P<$ 0.07 ) in our 2012 experiment, and would be horticulturally significant if reproduced consistently over seasons. The regimen with the intermediate mammalian toxicity (Regimen 7) was as effective as the most toxic regimen (Regimen 8) in reducing severe insect damage to the ears (Table 8). Most ears that were culls were filled, but had insect damage $>1 \frac{1}{2} 2$ inches from the cob tip (Table 9). When insect pressure was low to moderate, Bt sweet corn did not require supplementary insecticide applications to achieve $\geq 88 \%$ marketable ears (Speese et al., 2005). However, when insect pressure was extremely high, Bt sweet corn required two applications of $\lambda$-cyhalothrin to achieve $\geq 88 \%$ marketable ears (Speese et al., 2005).

\section{Conclusions}

Growers need to determine an appropriate planting window for fall sweet corn at their specific site. Planting too early will subject the crop to heat stress, resulting in stunted plants and poor quality ears. Planting too late will incur the risk of cold damage to the maturing plants. In eastern Oklahoma,

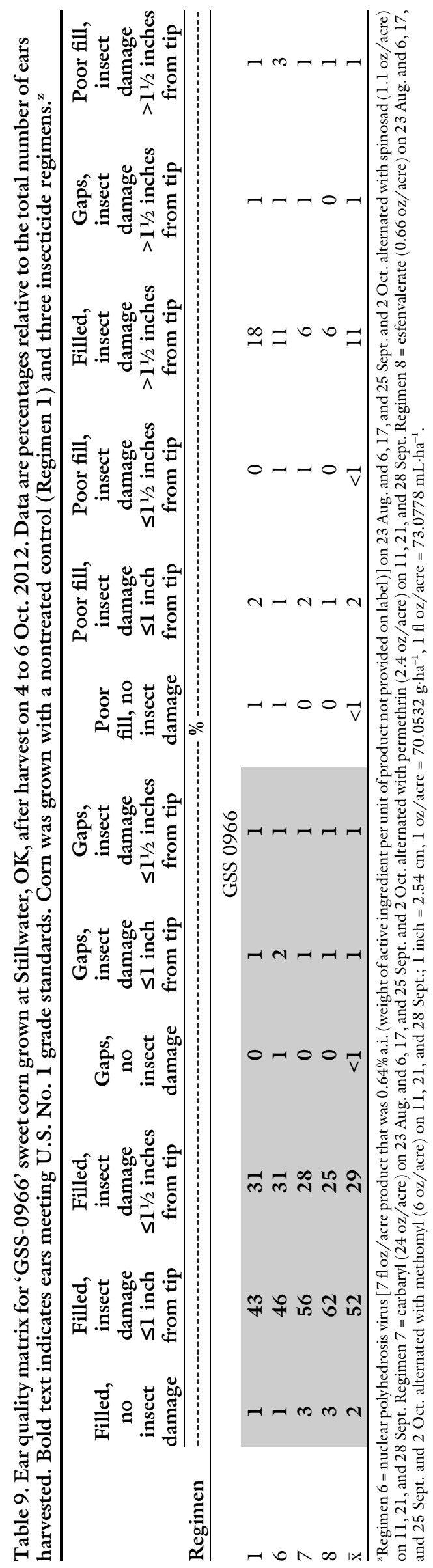

Hortlechnology $\cdot$ August 2016 26(4) 
a suitable planting window would correspond roughly to the last 2 weeks in July. Within this favorable period, it is possible to sow corn to a stand, but timely irrigation must be given. A seeding rate $\approx 1^{1 / 2}$ times the desired final stand appeared to be satisfactory.

We found that use of a cultivar with genetic resistance to lepidopteran pests was a critical factor for successful production of fall sweet corn. Efforts to produce a crop with a nontransgenic cultivar using insecticides with relatively low mammalian toxicity were unsuccessful. Speese et al. (2005) determined that a strategy of transgenic Bt sweet corn plus two applications of $\lambda$-cyhalothrin was profitable for a summer sweet corn crop in Virginia. Further studies are needed to determine whether supplemental insecticide applications are economically justified when growing a fall crop of transgenic Bt sweet corn in the south-central United States. Our experiments support previous recommendations for applying supplemental insecticides to transgenic Bt sweet corn to potentially increase production of "premium" ears by reducing the percentage of ears with insect damage $>1 \frac{1}{2}$ inches from the cob tip (Lynch et al., 1999b; Speese et al., 2005). We demonstrated that a spray schedule that rotated two insecticides with intermediate mammalian toxicity (carbaryl and permethrin) was as effective in reducing severe insect damage to ears of 'GSS0966' as a similar schedule that rotated two highly toxic insecticides (esfenvalerate and methomyl).

\section{Literature cited}

Balusu, R.R. and H.Y. Fadamiro. 2012. Evaluation of organically acceptable insecticides as stand-alone treatments and in rotation for managing yellowmargined leaf beetle, Microtheca ochroloma (Coleoptera: Chrysomelidae), in organic crucifer production. Pest Mgt. Sci. 68: 573-579.

Borror, D.J., D.M. DeLong, and C.A. Triplehorn. 1976. An introduction to the study of insects. 4th ed. Holt Rinehart Winston, New York, NY.

Brandenberger, L., B. Kahn, and E. Rebek. 2014. Sweet corn production. Coop. Ext. Serv., Oklahoma State Univ., Stillwater, OK, HLA-6021.

Brooking, I.R. and H.G. McPherson. 1989. The impact of weather on the scheduling of sweet corn for processing. 1. Quantifying the link between rate of development and the environment. N. Z . J. Crop Hort. Sci. 17:19-26.

Burkness, E.C., W.D. Hutchison, R.A. Weinzierl, J.L. Wedberg, S.J. Wold, and J.T. Shaw. 2002. Efficacy and risk efficiency of sweet corn hybrids expressing a Bacillus thuringiensis toxin for Lepidopteran pest management in the midwestern US. Crop Prot. 21:157-169.

Dimitri, C., J.C. Hanson, and L. Oberholtzer. 2012. Local food in Maryland schools: A real possibility or a wishful dream? J. Food Distrib. Res. 43:112-128.

Farrar, R.R., Jr., B.M. Shepard, M. Shapiro, R.L. Hassell, M.L. Schaffer, and C.M. Smith. 2009. Supplemental control of lepidopterous pests on Bt transgenic sweet corn with biologically-based spray treatments. J. Insect Sci. 9(1):8.

Garcia y Garcia, A., L.C. Guerra, and G. Hoogenboom. 2009. Impact of planting date and hybrid on early growth of sweet corn. Agron. J. 101:193-200.

Kish, S. 2008. From farm to school: Improving small farm viability and school meals. NRI Res. Highlights 2008. 19 Apr. 2016. <http://naldc.nal.usda.gov/ catalog/15377>.
Lonnquist, J.H. and R.W. Jugenheimer. 1943. Factors affecting the success of pollination in corn. J. Amer. Soc. Agron. 35:923-933.

Lynch, R.E., B.R. Wiseman, D. Plaisted, and D. Warnick. 1999a. Evaluation of transgenic sweet corn hybrids expressing CryIA (b) toxin for resistance to corn earworm and fall armyworm (Lepidoptera: Noctuidae). J. Econ. Entomol. 92:246-252.

Lynch, R.E., B.R. Wiseman, H.R. Sumner, D. Plaisted, and D. Warnick. 1999b. Management of corn earworm and fall armyworm (Lepidoptera: Noctuidae) injury on a sweet corn hybrid expressing a cryIA (b) gene. J. Econ. Entomol. 92:1217-1222.

Malvar, R.A., P. Revilla, P. Velasco, M.E. Cartea, and A. Ordás. 2002. Insect damage to sweet corn hybrids in the south Atlantic European coast. J. Amer. Soc. Hort. Sci. 127:693-696.

Musser, F.R. and A.M. Shelton. 2003. Bt sweet corn and selective insecticides: Impacts on pests and predators. J. Econ. Entomol. 96:71-80.

Nuessly, G.S., B.T. Scully, M.G. Hentz, R. Beiriger, M.E. Snook, and N.W. Widstrom. 2007. Resistance to Spodoptera frugiperda (Lepidoptera: Noctuidae) and Euxesta stigmatias (Diptera: Ulidiidae) in sweet corn derived from exogenous and endogenous genetic systems. J. Econ. Entomol. 100:1887-1895.

Offner, J. 2011. Winter puts a chill on going local. The Packer 118(31):C-6.

Speese, J., III., T.P. Kuhar, A.D. Bratsch, B. A. Nault, V.M. Barlow, R.J. Cordero, and Z-X. Shen. 2005. Efficacy and economics of fresh-market $B t$ transgenic sweet corn in Virginia. Crop Protection 24:57-64.

Williams, M.M., II. 2008. Sweet corn growth and yield responses to planting dates of the north central United States. HortScience 43:1775-1779. 